\title{
Effect of dietary protein on the growth of mullet, Chelon labrosus, reared in sea cages
}

\author{
Muhammet Altunok, Osman Özden
}

Received - 10 April 2016/Accepted - 14 August 2017. Published online: 30 September 2017; @Inland Fisheries Institute in Olsztyn, Poland Citation: Altunok M., Özden O. 2017 - Effect of dietary protein on the growth of mullet, Chelon labrosus, reared in sea cages - Arch. Pol. Fish. 25: 157-164.

\begin{abstract}
The purpose of the study was to obtain preliminary data on the effect of dietary protein on the growth of the thick-lipped grey mullet (Chelon labrosus) juveniles reared in net sea-cages. The juveniles $(6.2 \pm 0.61 \mathrm{~g})$ were obtained from the wild and were stocked into net sea-cages at a stocking rate of 100 juveniles per cubic meter and fed with experimental diets including 25, 30, or 35\% crude protein for 87 days. The highest mean weight and specific growth rate (SGR) were 39.5 g and $2.13 \%$ day $^{-1}$, respectively, at protein levels of $30 \%$. The diet also resulted in the most efficient feed conversion ratio of 1.61 .
\end{abstract}

Keywords: Chelon labrosus, dietary protein, growth, cage culture

\section{Introduction}

Mullet species are popular food fishes, and rearing them in aquaculture has recently attracted attention worldwide. The need to diversify marine aquaculture products in the Mediterranean has stimulated the farming of new species (Biandolino et al. 2010). Mullet species are considered to be potential candidates for the diversification of marine aquaculture since

M. Altunok [@”]

Limburger Str. 4, 35260, Stadtallendorf, Germany

e-mail: muhammet.altunok@hotmail.de

Osman Özden

Ege University, Faculty of Fisheries, Bornova-Izmir 35100, Turkey they have good biological characteristics, are in great demand, and obtain high market prices in Mediterranean countries. Mullet species are farmed primarily in brackish waters using extensive techniques in lagoons and coastal areas and with various culture methods with additional feeding and fertilization practiced in some countries (Cataudella et al. 2005). There are also reports of culturing mullet species in freshwater and brackish water ponds (Barman et al. 2005, Biswas et al. 2012). The salinity tolerance of mullet species, which has been reported previously, permits good growth in a variety of ecosystems and is evidence of their potential in various aquaculture systems (Hotos and Vlahos 1998).

Mugil cephalus, Chelon labrosus, Liza aurata, Liza saliens and Liza ramada are the most commonly farmed mullet species in Mediterranean countries, which are the largest producers of various mullet species (El-Sayed and El-Ghobashy 2011). Because of wild-caught fish pressure on environment, in recent years increasing attention has been focused on research concerning hatchery-produced seeds and larval rearing of mullet species in the region (Cataudella et al. 1988, Khemis et al. 2006, El-Sayed and El-Ghobashy 2011). On the other hand, not enough information is available regarding feed utilization or growth performance of mullets species fed artificial feeds. Previous studies have mostly investigated the ecology and feeding habits of wild mullet species. Similar to most of other

(c) Copyright by Stanisław Sakowicz Inland Fisheries Institute in Olsztyn.

(c) 2017 Author(s). This is an open access article licensed under the Creative Commons Attribution-NonCommercial-NoDerivs License

(http://creativecommons.org/licenses/by-nc-nd/3.0/). 
mugilids, the thick-lipped grey mullet has been described as an omnivorous, planktivorous fish that feed on detritus, benthic organisms, and algae (Brusle 1981). Therefore, it seems that natural sources and low cost feeds can be used to meet the nutritional requirement of this species. Accordingly, research on mullet feeding have focused on evaluating different protein sources and how they influence growth and feed utilization in mullet species (Wassef et al. 2001, Belal 2004, Luzzana et al. 2005). In one previous study, it was demonstrated that the use of algae-based diets in C. labrosus has limitations with respect to growth performance and feed utilization (Davies et al. 1997). The main function of food is to meet fish energy requirements for maintenance, growth, and reproduction. For C. labrosus to grow at optimal rates, adequate quantities of energy must be provided, and lipids are thought to be a more effective source of non-protein energy than are carbohydrates (Ojaveer et al. 1996). Protein requirements of some mugilids have also been studied (Papaparaskeva-Papoutsoglou and Alexis 1986, El-Sayed 1991, Lin et al. 1998, Carvalho et al. 2010). In addition, several fish feeds (e.g., for sea bream, trout, carp) have been tested (Höner et al. 1989, Cardona and Castello 1995, Ağirağac and Kalma 1999), but the results were not as encouraging as predicted.

No commercial diets are available for mullet species in many countries. The availability of efficient feed is a certainly a bottleneck in enhancing the production of these species in fish culture, and it is necessary to determine the nutritional requirement of species under culture conditions in oder to formulate well-balanced, low cost, environmentally-friendly diets. Additionally, advancing mullet aquaculture depends on the development of intensive-farming techniques, which are currently also limited for these species. Environmental issues and potential conflict of interests among sectors in coastal zones are also considered important driving forces in open-sea farming (Burbridge et al. 2001). Little information is available on the growth of mullet species in sea-cages, and diets containing various levels of protein have yet to be studied under natural conditions. The present study was conducted to investigate adaptive responses and evaluate the effects of dietary protein on the growth performance of $C$. labrosus reared in cages.

\section{Materials and methods}

Juvenile mullet were obtained the wild in Siğacik-Seferihisar Estuary (Turkey). The fish were stocked into fiberglass tanks at the Hatchery Unit of the Faculty of Fisheries, University of Ege (Izmir, Turkey) for acclimation to artificial feeding and rearing conditions. The fish were anesthetized with 2-phenoxyethanol (0.2 ppt) and were weighed (6.2 \pm $0.61 \mathrm{~g}$ mean body weight) before being stocked into sea-cages (Urla-Izmir). Twelve net sea-cages (1.5 x 1 $\mathrm{x} 1 \mathrm{~m}$; depth $\mathrm{x}$ length $\mathrm{x}$ width) with water volumes of $1 \mathrm{~m}^{3}$ each and $10 \mathrm{~mm}$ mesh size were suspended from floating platforms. The net sea-cages were covered with protective net to keep the fish from escaping by jumping out and to protect them from bird predation. Stocking density was 100 fish per sea-cage and growth was compared using formulated, floating diets containing 25, 30, and 35\% protein (Table 1) in triplicate. Thirty fish per replicate were sampled and weighed at two-week intervals throughout the feeding trial. The fish were fed four times daily to apparent satiation, and consumption was recorded during the experimental period. Mortalities, water temperature, and dissolved oxygen in the sea-cages were recorded daily. Salinity and $\mathrm{pH}$ were measured weekly.

\section{Diet preparation and chemical analysis}

Three isocaloric $\left(19.6 \pm 0.2 \mathrm{MJ} \mathrm{kg}^{-1}\right)$ diets containing 25 , 30, or $35 \%$ crude protein were formulated according to published nutrients requirements of mullet (Table 1). Locally produced fish meal (FM), soybean meal, and corn meal were used as the protein sources. The dietary ingredients were blended, moistened, and cold pelleted with a laboratory feed mill. The pellets were then dried at $40^{\circ} \mathrm{C}$ for 24 hours and stored at $-20^{\circ} \mathrm{C}$ until delivery. Experimental diet 
Table 1

Formulation and composition of the test diets

\begin{tabular}{|c|c|c|c|c|}
\hline \multirow[b]{2}{*}{ Ingredients (\%) } & \multicolumn{3}{|c|}{ Dietary protein level (\%) } & \multirow[b]{2}{*}{ Carp feed } \\
\hline & 25 & 30 & 35 & \\
\hline Fish meal & 15 & 20 & 30 & \\
\hline Soybean meal & 25 & 30 & 30 & \\
\hline Wheat meal & 30 & 25 & 18 & \\
\hline Corn meal & 20 & 15 & 12 & \\
\hline Vitamin premix ${ }^{\mathrm{a}}$ & 1.7 & 1.7 & 1.7 & \\
\hline Mineral premix ${ }^{b}$ & 1 & 1 & 1 & \\
\hline Cod-liver oil & 7 & 7 & 7 & \\
\hline Lignosulfonate & 0.3 & 0.3 & 0.3 & \\
\hline \multicolumn{5}{|l|}{ Proximate composition } \\
\hline Dry matter & 91.35 & 91.95 & 91.55 & 91.33 \\
\hline Crude protein & 25.53 & 30.13 & 35.58 & 36.45 \\
\hline Crude lipid & 12.03 & 12.08 & 12.38 & 10.3 \\
\hline Ash & 8.8 & 9.22 & 10.05 & 9.4 \\
\hline Crude fibre & 2.96 & 3.09 & 2.99 & 5.3 \\
\hline NFE & 50.68 & 45.48 & 39.00 & 38.55 \\
\hline $\mathrm{GE}\left(\mathrm{MJ} \mathrm{kg}^{-1}\right)$ & 19.49 & 19.71 & 20.01 & 19.32 \\
\hline $\mathrm{P}: \mathrm{E}$ (g protein $\left.\mathrm{MJ} \mathrm{kg}{ }^{-1} \mathrm{GE}\right)$ & 13.10 & 15.28 & 17.78 & 18.87 \\
\hline
\end{tabular}

${ }^{a}$ Per kg premix: vitamins A: 4000000 IU, D $: 480000$ IU, K ${ }_{3}: 2.4$ g, B 14 g, B2: 6 g, B 6 : 4 g, B $12: 10$ mg, Ca-panthothenate: 10 g; D-biotin: $100 \mathrm{mg}$; folic acid: $1.2 \mathrm{~g}$; inositol: $60 \mathrm{~g}$ and $40 \mathrm{~g}$ niacin, vitamin $\mathrm{E}$ and $\mathrm{C}$

${ }^{\text {b }}$ Per kg premix: 23.75 g Mn, 75 g Zn, 5 g Cu, 2 g Co, 2.75 g I, 100 mg Se, 200 g Mg

dry matter, crude ash, crude protein, and crude lipid contents were determined by 24 -h drying at $105^{\circ} \mathrm{C}$, 12-h combustion at $525^{\circ} \mathrm{C}$, the Kjeldahl method $(\mathrm{N} \times 6.25)$, and petroleum ether extraction (Horwitz et al. 2000). The nitrogen-free extract (NFE) was calculated by subtracting the sum of crude ash, crude protein, and crude lipid from 100 . The energy content of the test diets was estimated using conversion factors of 39.5, 23.7, and $17.2 \mathrm{~kJ} \mathrm{~g}^{-1}$ for fat, protein, and carbohydrate, respectively (Brett and Groves 1979). The suitability of commercially available carp feed was also tested to compare it with the experimental diets. The results were expressed as mean \pm SD and analyzed with one-way ANOVA to test the effect of the dietary protein levels. Post hoc analysis was conducted using Duncan's new multiple range test with the statistical significance set at the 0.05 probability level to compare mean values among treatments. Additionally, the optimal dietary protein level was determined with the broken-line model method. Percentage data were normalized using arcsin transformation before analysis. All statistical analysis was performed using SPSS Statistics version 20.0 (IBM, New York).

\section{Results}

The fish were well adapted to the net-cages, accepted the diets regardless of dietary protein content, and no mortality was recorded under natural conditions after stocking into the sea-cages or for the further two-week period. Recorded water temperatures, dissolved oxygen, salinity, and $\mathrm{pH}$ were all within ranges suitable for fish culture (Fig. 1). There were no significant differences in the water quality parameters among the levels in the sea-cages or the ambient environment. Final mean weights and specific growth rates (SGR) were higher for the fish fed with $30 \%$ dietary protein (Table 2 ). No significant $(\mathrm{P}>$ 0.05) effect of increasing dietary protein level from 30 to $35 \%$ was observed on fish growth (Table 2), whereas the fish fed the commercial carp feed (36.5\% protein) exhibited a markedly reduced growth rate 
Table 2

Performance of fish fed diets with varied protein levels (mean \pm SD)

\begin{tabular}{|c|c|c|c|c|}
\hline \multirow[b]{2}{*}{ Parameters } & \multicolumn{3}{|c|}{ Dietary protein level (\%) } & \multirow[b]{2}{*}{ Carp feed } \\
\hline & 25 & 30 & 35 & \\
\hline Initial body weight (g) & $6.2 \pm 0.5^{\mathrm{a}}$ & $6.2 \pm 0.5^{\mathrm{a}}$ & $6.2 \pm 0.6^{\mathrm{a}}$ & $6.3 \pm 0.7^{\mathrm{a}}$ \\
\hline Final weight $(\mathrm{g})$ & $29.1 \pm 1.0^{\mathrm{a}}$ & $39.5 \pm 1.9^{b}$ & $35.1 \pm 1.6^{\mathrm{bc}}$ & $33.7 \pm 1.1^{\mathrm{c}}$ \\
\hline SGR $\left(\%\right.$ day $\left.^{-1}\right)$ & $1.77 \pm 0.04^{\mathrm{a}}$ & $2.13 \pm 0.05^{\mathrm{b}}$ & $1.99 \pm 0.05^{\mathrm{bc}}$ & $1.94 \pm 0.04^{\mathrm{c}}$ \\
\hline FCR & $2.10 \pm 0.09^{\mathrm{a}}$ & $1.61 \pm 0.07^{\mathrm{b}}$ & $1.78 \pm 0.06^{\mathrm{bc}}$ & $1.84 \pm 0.04^{\mathrm{c}}$ \\
\hline PER & $2.39 \pm 0.07^{\mathrm{a}}$ & $2.46 \pm 0.09^{\mathrm{a}}$ & $1.92 \pm 0.05^{b}$ & $1.83 \pm 0.05^{\mathrm{b}}$ \\
\hline Survival (\%) & $96.0 \pm 0.6^{\mathrm{a}}$ & $98.3 \pm 0.3^{b}$ & $98.3 \pm 0.7^{\mathrm{b}}$ & $98.0 \pm 0.0^{\mathrm{b}}$ \\
\hline Biomass (kg) & $2789.8 \pm 106.4^{\mathrm{a}}$ & $3887.0 \pm 187.3^{b}$ & $3454.5 \pm 163.7^{\mathrm{bc}}$ & $3307.5 \pm 101.1^{\mathrm{c}}$ \\
\hline
\end{tabular}

Means in rows with different superscripts are significantly different $(\alpha=0.05)$. SGR ( $\%$ day $\left.{ }^{-1}\right)$ : 100 (Ln final weight - Ln initial weight)/days. FCR: dry feed intake (g)/weight gain $(\mathrm{g})$. PER: weight gain $(\mathrm{g}) /$ protein intake $(\mathrm{g})$

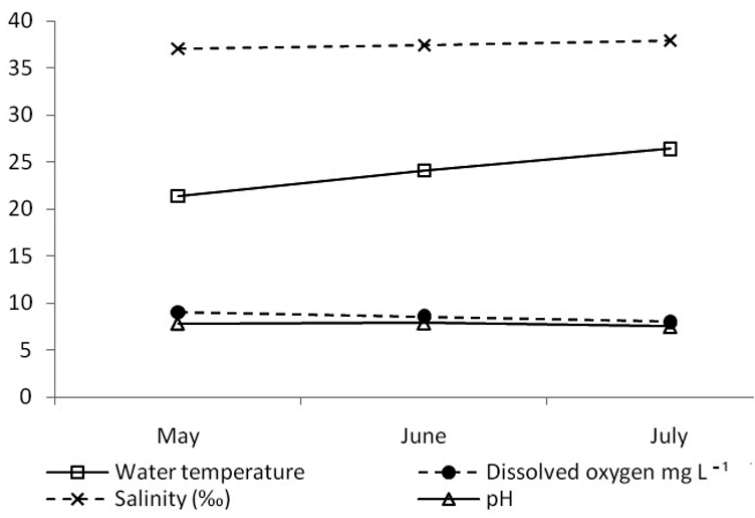

Figure 1 . Water quality parameters during the feeding trial.

$(\mathrm{P}<0.05)$. Regression analysis indicated that the maximum SGR occurred at a $31.6 \%$ protein level (Fig. 2).

Mortalities in groups usually occurred following handling and can be attributed to manipulation stress. However, fish mortality in the $25 \%$ dietary protein group was recorded mostly during the last period of the experiment and not following handling. This could also be caused by manipulation injuries or could be attributed to some extent to other, unknown stress factors.

Biomass was similar until day 51 , but this diverged thereafter. The effect of dietary protein on final yield in the sea-cage culture of thick-lipped grey mullet was highly significant $(\mathrm{P}<0.05)$ when the fish

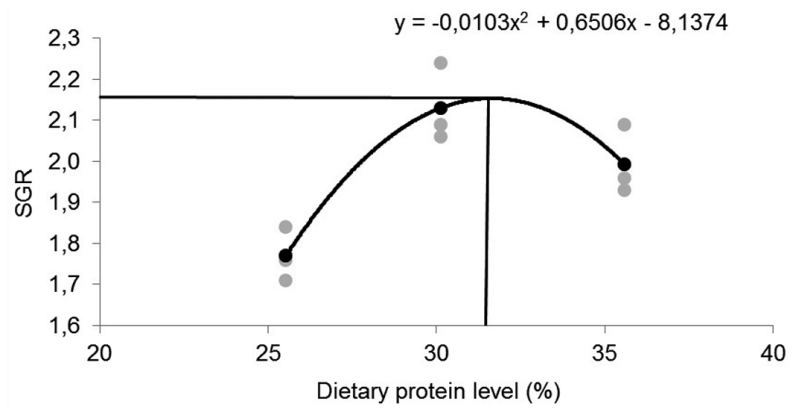

Figure 2. Second-order polynomial fitting of SGR to dietary protein level.

were fed 30\% dietary protein. Fish growth was depressed when dietary protein was decreased below or increased above this protein level. Lower feed conversion (1.61) ratios were detected in the fish fed the diet containing 30\% dietary protein, and on either side of this level, feed conversion ratio (FCR) deteriorated with either increased or decreased protein levels. Protein efficiency ratio (PER) ranged from 1.85 to 2.46 and was negatively correlated with dietary protein.

\section{Discussion}

Comparisons of studies are complicated by experimental variations including those regarding fish species, fish sizes and ages, protein quality, diet formulations, culture systems, duration, salinity, and stocking density and also by mullet diet variation 
depending on species, age, location, and season (Brusle 1981). In a previous study, the growth rates of L. macrolepis and M. cephalus fed $40 \%$ protein diets ranged from 0.1 to $0.3 \mathrm{~g}$ day $^{-1}$ in cages in brackish water and in a power plant cooling (Jones and Strawn 1982, 1983); whereas the growth of fish was $0.4 \mathrm{~g} \mathrm{day}^{-1}$ in our study. This outcome was attributable to salinity, since growth and feed utilization have been found to increase, and feed conversion ratios to decrease, with increasing salinity (up to 36\%) in mullet (El-Sayed 1991). Nevertheless, in tanks (30\%o seawater), Baker et al. (1998) reported an SGR of $1.51 \%$ day $^{-1}$ for thick-lipped grey mullet (11-30 g body weight) fed a $38 \%$ protein diet.

Davies et al. (1997) reports higher SGR (3\% day $^{-1}$ ) when thick-lipped grey mullet were fed a diet with $47 \%$ protein containing $68 \%$ fish meal in a seawater (30-33\%) aquarium system, whereas partial replacement of the fishmeal (33\%) with seaweed meal (56\%) resulted in decreased growth $(2.4 \%$ day $\left.^{-1}\right)$. The amount of fish meal in the study cited above was still higher and the fish were smaller (1-9 g), which could be, in part, the explanation of some higher SGR when compared to the present study. In fact, growth $\left(1.2 \%\right.$ day $\left.^{-1}\right)$ was not improved by the addition of $85 \%$ fish meal to the diet (38-59\% protein) of thick lipped grey mullet (15.2-41.6 g) in seawater tanks (Ojaveer et al. 1996). Wassef et al. (2001) obtained comparable growth rates $\left(2.1-2.4 \%\right.$ day $\left.^{-1}\right)$ to those of the present study with a $41 \%$ protein diet (fishmeal $=20-35 \%)$ in $M$. cephalus $(6.4 \mathrm{~g}$ ) reared in fixed cages in a pond (salinity, 8\%o), but the stocking rate was six times less than that in the preset study. The mullet species seemed to respond differently individually to the same vegetable proteins (Wassef et al. 2001, Luzzana et al. 2005, El-Dahhar et al. 2013), and the different amino acid profiles of vegetable proteins could partially explain these differences. The results of the present study indicate that the diet containing 20\% fishmeal and 30\% soybean seems to be the most economical and appropriate than other diets for rearing fish in sea-cage culture as profitability depends mainly on the cost of feed production, feed conversion, and fish growth and survival rates. Our results are also in broad agreement with those of other authors who found that dietary protein levels between $28-35 \%$ induced optimum growth and feed utilization in mullet species under laboratory conditions (Lin et al. 1998, Argyropoulou et al. 1992, Yoshimatsu et al. 1992). Additionally, these early studies clearly recognized that there is a trend toward decreasing dietary protein requirements with age. Dietary protein levels of 30-40\% were determined to be optimal for growth and feed conversion in the production of L. ramada, M. platanus, and L. macrolepis (up to $1.5 \mathrm{~g}$ ) at different salinities ranging from 0 to 36\% (El-Sayed et al. 1991, Carvalho et al. 2010). On the other hand, optimal dietary protein requirement of $M$. capito juveniles up to $10 \mathrm{~g}$ ranged from 24 to $36 \%$ under full seawater conditions (Papaparaskeva-Papoutsoglou and Alexis 1986). The present study revealed that the growth of thick-lipped grey mullet (40 g body weight) fed with a $30 \%$ protein diet was comparable to that of fish fed with higher protein diets in sea-cages.

The type of culture method (raceway, cage, open ponds, etc.) can also affect optimum protein intake of fish species because nutrient requirements determined for certain nutrients under optimum conditions increase when fish are exposed to environmental conditions such as poor water quality, waves, rain, stress, pathogens, etc. (Izquierdo and Robaina 2000). Since extreme variations were not observed during the experimental period, rearing environment could be another promising factor affecting growth production. Also, unlike most of previous experiments conducted indoors (e.g., in aquariums or tanks), our study was undertaken in net sea-cages where a portion of the feed delivered could have been lost (even if it was minimized) because of currents. FCR, which was calculated using the amount of feed offered rather than the actual intake, therefore, should be lower if exact feed intake data is to be obtained. In the present study, the feed efficiency reached a plateau with a protein level of $30-35 \%$. Such trends have been reported previously for mullet species (Papaparaskeva-Papoutsoglou and Alexis 1986, El-Sayed 1991, Carvalho et al. 2010). The utilization of dietary protein for fish is linked with the balance between dietary protein and non-protein 
energy; therefore, excess protein in the diet is catabolized as an energy source (Carvalho et al. 2010), or it can depress growth because of higher energy requirements (Siddiqui and Khan 2009). Although our $35 \%$ protein diet had a slightly higher protein to carbohydrate ratio, which Ojaveer et al. (1996) also reports to promote fast growth in thick-lipped grey mullet, growth rates were not significantly different between the 30 and 35\% dietary protein groups. Digestibility and energy content had variable effects on fish performance (Trung et al. 2011). In our study, growth depression was observed in the fish fed carp feed (36.5\% protein). This might be explained by the composition of the carp feed, which contained high levels of indigestible fibre and/or low levels of dietary lipid concentration. Dietary lipids can be considered to be a better source of non-protein energy than carbohydrates in mullet species and in other fish species (Jones and Strawn 1983, Argyropoulou et al. 1992). The FCR in the present study was superior to those reported previously (1.8-4.9) for mullet species (Jones and Strawn 1983, Papaparaskeva-Papoutsoglou and Alexis 1986, Davies and Brown 1997, Barman et al. 2005). Moreover, FCR increased in the fish group fed carp feed, but it was still considerably better than those observed in previous studies on mullet species fed carp, trout, or seabream feeds in sea-cages, ponds, and recirculating aquaculture systems (Höner et al. 1989, Sanchez et al. 1993, Cardona and Castello 1995, Ağirağac and Kalma 1999). In the present study, the availability of natural plankton food in the sea-cages could also explain the favorably lower FCR. Further investigation is required to better understand the effects of mullet feeding on plankton depending on stocking density in sea-cages. The variations could also be attributed to water temperature, which affects feed consumption (Soderberg 1992, Watanabe et al. 2001), and was in the range $\left(20-32^{\circ} \mathrm{C}\right)$ for the optimum growth of mullet species (Marin and Dodson 2000, El-Dahhar et al. 2013) in the present study. PER was the highest when the dietary protein requirement was met and appeared to decrease with increasing dietary protein content at the same energy level. Similar trends are reported for mullet and other species (El-Sayed 1991, Carvalho et al. 2010). The present findings also indicated a considerable reduction in PER with carp feed. An increase in the dietary energy level at lower dietary protein levels improves the efficiency of protein utilization and retention (Ali et al. 2008). Therefore, this reduction in carp feed probably results from the low lipid content or the types of vegetable proteins, as is mentioned above. However, the observed PER values were considerably higher than those reported previously (1.16-0.93) for C. labrosus and M. cephalus (Davies and Brown 1997, Wassef et al. 2001).

In conclusion, it is increasingly necessary to diversify aquaculture products with a focus on developing open sea and sustainable aquaculture in the face of threats from pollution risks and limited freshwater sources. The current findings indicate that $30 \%$ dietary protein can be utilized in the sea-cage farming of mullet species without any pathological symptoms or mortality. Further studies should be conducted to investigate the effect of diet quality and feed utilization when rearing market-sized mullet in cages at high stocking densities.

Author contributions. M.A. conceived the study and designed with O.Ö., who supervised the research work. M.A. performed the experiment, collected and analyzed the measurements, and wrote the paper.

\section{References}

Ağirağaç G., Kalma M. 1999 - A research on the growth rate on the mullet (Mugil auratus Risso, 1810) fingerlings fed different diets in cages - Turk. J. Vet. Anim. Sci. 23: 751-756 (in Turkish).

Ali A., Al-Ogaily S.M., Al-Asgah N.A., Goddard J.S., Ahmed S.I. 2008 - Effect of feeding different protein to energy $(\mathrm{P} / \mathrm{E})$ ratios on the growth performance and body composition of Oreochromis niloticus fingerlings - J. Appl. Ichthyol. 24: 31-37.

Horwitz W., Chichilo P., Reynolds H. 2000 - Official methods of analysis of the Association of Official Analytical Chemists, Inc., USA.

Argyropoulou V., Kalogeropoulos N., Alexis M.N. 1992 Effect of dietary lipids on growth and tissue fatty acid composition of grey mullet (Mugil cephalus) - Comp. Biochem. Physiol. 101A: 129-35. 
Baker R.T.M., Handy R.D., Davies S.J., Snook J.C. 1998 Chronic dietary exposure to copper affects growth, tissue lipid peroxidation, and metal composition of the grey mullet, Chelon labrosus - Mar. Environ. Res. 45: 357-365.

Barman U.K., Jana S.N., Garg S.K., Bhatnagar A., Arasu A.R.T. 2005 - Effect of inland water salinity on growth, feed conversion efficiency and intestinal enzyme activity in growing grey mullet, Mugil. cephalus (Linn.): Field and laboratory studies - Aquacult. Int. 13: 241-256.

Belal I.E.H. 2004 - Replacement of corn with mangrove seeds in bluespot mullet Valamugil seheli diets - Aquacult. Nutr. 10: 25-30.

Biandolino F., Portacci G., Prato E. 2010 - Influence of natural diet on growth and biochemical composition of Octopus vulgaris Cuvier, 1797 - Aquacult. Int. 18: 1163-1175.

Biswas G., De D., Thirunavukkarasu A.R., Natarajan M., Sundaray J.K., Kailasam M., Kumar, P., Ghoshal T.K., Ponniah A.G., Sarkar A. 2012 - Effects of stocking density, feeding, fertilization and combined fertilization-feeding on the performances of striped grey mullet (Mugil cephalus L.) fingerlings in brackishwater pond rearing systems - Aquaculture 338-341: 284-292.

Brett J.R., Groves T.D.D. 1979 - Physiological energetics - In: Fish Physiology Vol 8 (Eds) W.S. Hoar, D.J. Randall, J.R. Brett, Academic Press, New York: 279-352.

Brusle J. 1981 - Food and feeding in grey mullet - In: Aquaculture of Grey Mullets (Ed.) O.H. Oren: 185-217.

Burbridge P., Hendrick V., Roth E., Rosenthal H. 2001 Social and economic policy issues relevant to marine aquaculture - J. Appl. Ichthyol. 17: 194-206.

Cardona L., Castello F. 1995 - Effectividad del pienso para dorado y del pienso para carpa en el preengorde de Mugil cephalus - Actas Del V Congreso Nacional Acuicultura, Spain.

Carvalho C.V.A., Bianchini A., Tesser M.B., Sampaio L.A. 2010 - The effect of protein levels on growth, postprandial excretion and tryptic activity of juvenile mullet Mugil platanus (Günther) - Aquac. Res. 41: 511-518.

Cataudella S., Massa F., Rampacci M., Crosetti D. 1988 Artificial reproduction and larval rearing of the thick-lipped mullet (Chelon labrosus) - J. Appl. Ichthyol. 4: 130-139.

Cataudella S., Massa F., Crosetti D. 2005 - Interactions between aquaculture and capture fisheries: a methodological perspective - Studies and Reviews. General Fisheries Commission for the Mediterranean, No. 78, Rome, FAO. 229 p.

Davies S.J., Brown M.T., Camilleri M. 1997 - Preliminary assessment of the seaweed Porphyra purpurea in artificial diets for thick-lipped grey mullet (Chelon labrosus) Aquaculture 152: 249-258.
El-Dahhar A.A., Salama M.E., Moustafa Y.T., El-Morshedy E.M. 2013 - Effect of using sea weeds in grey mullet (Liza ramada) larval diets on growth performance and feed utilization - Journal of the Arabian Aquaculture Society 8: 217-228.

El-Sayed A.F.M. 1991 - Protein requirements for optimum growth of Liza ramada fry (Mugilidae) at different water salinities - Aquat. Living Resour. 4: 117-123.

El-Sayed A.F.M., El-Ghobashy A.E. 2011 - Effects of tank colour and feed colour on growth and feed utilization of thinlip mullet (Liza ramada) larvae - Aquacult. Res. 42: 1163-1169.

Höner G., Hillers A., Konjevic D., Milojevic S. 1989 - Growth of mullet (Liza ramada) fed three commercial trout and eel feeds in open and closed aquaculture systems - J. Appl. Ichthyol. 5:157-64.

Hotos G.N., Vlahos N. 1998 - Salinity tolerance of Mugil cephalus and Chelon labrosus Pisces: Mugilidae fry in experimental conditions - Aquaculture 167: 329-338.

Izquierdo M., Robaina L. 2000 - Methodological strategies for the determination of nutrient requirements in finfish. Recent advances in Mediterranean aquaculture finfish species diversification - CIHEAM (n. 47). Zaragoza, 25-41.

Jones F.V., Strawn K. 1982 - Aspects on the growth and feeding behavior of cage-polycultured marine fish in a heated water system - J. World Maricul. Soc. 13: 187-197.

Jones F.V., Strawn K. 1983 - Growth and food utilisation of caged Atlantic croaker and striped mullet reared on various lipid diets in a heated water system - J. World Maricul. Soc. 14: 590-594.

Khemis I.B., Zouiten D., Besbes R., Kamoun F. 2006 - Larval rearing and weaning of thick lipped grey mullet (Chelon labrosus) in mesocosm with semi-extensive technology Aquaculture 259: 190-201.

Lin H., Jiang Q., Huang J., Shi H. 1998 - A preliminary study on the optimum protein level and protein to energy ratio of the diet for Mugil cephalus - Journal of the Shanghai Fisheries University 7: 187-192.

Luzzana U., Valfrè F., Mangiarotti M., Domeneghini C., Radaelli G., Moretti V.M., Scolari M. 2005 - Evaluation of different protein sources in fingerling grey mullet Mugil cephalus practical diets - Aquacult. Int. 13: 291-303.

Marin B.J., Dodson J.J. 2000 - Age, growth and fecundity of the silver mullet, Mugil curema (Pisces: Mugilidae), in coastal areas of northeastern Venezuela - Rev. Biol. Trop. 48: 389-398.

Ojaveer H., Morris P.C., Davies S.J., Russell P. 1996 - The response of thick-lipped grey mullet, Chelon labrosus, to diets of varied protein-to-energy ratio - Aquacult. Res. 27: 603-612. 
Papaparaskeva-Papoutsoglou E., Alexi M.N. 1986 - Protein requirement of young grey mullet, Mugil capito Aquaculture 52: 105-115.

Sanchez A., Cardona L., Castello F. 1993 - Crecimiento de alevines de Liza ramada (Osteichthyes, Mugilidae) en agua dulce: effectos de la alimentacion - In: Actas del IV Congreso Nacional De Acuicultura. Vilanova de Arousa, Spain.

Siddiqui T.K., Khan M.A. 2009 - Effects of dietary protein levels on growth, feed utilization, protein retention efficiency and body composition of young Heteropneustes fossilis (Bloch) - Fish Physiol. Biochem. 35: 479-488.

Soderberg R.W. 1992 - Linear fish growth models for intensive aquaculture - Prog. Fish Cult. 54: 255-258.

Trung D.V., Diu N.T., Hao N.T., Glencross B. 2011 - Development of a nutritional model to define the energy and protein requirements of tilapia, O. niloticus Aquaculture 320: 69-75.

Wassef E.A., Elmasry M.H., Mikhail F.R. 2001 - Growth enhancement and muscle structure of striped mullet, Mugil cephalus L., fingerlings by feeding algal meal-based diets - Aquacult. Res. 32: 315-322.

Watanabe W.O., Ellis S.C., Chaves J. 2001 - Effects of dietary lipid and energy to protein ratio on growth and feed utilization of juvenile mutton snapper Lutjanus analis fed isonitrogenous diets at two temperatures - J. World. Aquacult. Soc. 32: 30-40.

Yoshimatsu T., Furuichi M., Kitajima C. 1992 - Optimum level of protein in purified experimental diets for redlip mullet (L. haematocheila) - Nippon Suisan Gakk. 58: 2111-2117. 